\title{
Characterization of the cGMP-dependent protein kinase SmcGK1 of Schistosoma mansoni
}

\author{
SILKE LEUTNER, SVENJA BECKMANN and CHRISTOPH G. GREVELDING \\ Institute for Parasitology, Justus-Liebig-University Giessen, Rudolf-Buchheim-Strasse 2, 35392 Giessen, Germany \\ Manuscript received on December 13, 2010; accepted for publication on March 14, 2011
}

\begin{abstract}
Schistosomes are trematode parasites and of worldwide medical importance for humans and animals. Growth and development of these parasites require a specific host environment, but also permanent communication processes between the two genders. Accumulating molecular evidence indicates that the responsible interactions are mediated by signal transduction processes. Conserved signaling molecules were identified, and first approaches made for their characterization. However, no representative of the conserved family of cGMP-dependent protein kinases (cGKs) has been described in this parasite yet. Within the Schistosoma mansoni genome data-set we identified cGK homologs, of which one was investigated in more detail in this study. We present the cloning of SmcGK1, whose sequence shows homology to cGKs of higher eukaryotes. SmcGK1 was found to be gender-independently transcribed in adult schistosomes. The occurrence of SmcGK1 sense and antisense transcripts suggests that the expression of this gene is controlled at the post-transcriptional level. In situ hybridization experiments demonstrated a gonad-preferential expression profile in both genders indicating a role of SmcGK1, at least during sexual development of schistosomes. Using a cGK-specific inhibitor to treat adult schistosomes in vitro finally resulted in a multifaceted phenotype including slow motion, oocyte congestion, and reduced egg production.
\end{abstract}

Key words: Schistosoma mansoni, signal transduction, cGMP-dependent protein kinases (cGKs), serine/threonine (S/T) kinases, gonad development.

\section{INTRODUCTION}

Cyclic guanosine-3', 5'-monophosphate (cGMP)-dependent protein kinases (cGKs) belong to the group of serine/threonine $(\mathrm{S} / \mathrm{T})$ kinases. There are two genes known, coding for cGKs I and II in higher eukaryotes. The cGKI isoforms cGKIalpha and cGKIbeta are expressed in smooth muscle cells, platelets, and in neuronal tissue such as Purkinje cells, hippocampal neurons, and the lateral amygdale. cGKII is active in the secretory epithelium of the small intestine, the juxtaglomerular cells, the adrenal cortex, the chondrocytes, and in the nucleus suprachiasmaticus (Pfeifer 1999 et

Correspondence to: Christoph G. Grevelding

E-mail: Christoph.Grevelding@vetmed.uni-giessen.de al., Hofmann et al. 2009). Both cGKs are effectors in $\mathrm{NO} / \mathrm{cGMP}$ and the ANP/cGMP signaling pathways. cGKI function is involved in muscle tone relaxation and prevents platelet aggregation. cGKII function inhibits renin secretion, chloride/water secretion in the small intestine, circadian rhythm, and endochondreal bone growth. Beyond that cGKs are modulators of cell growth (Hofmann et al. 2009). In Caenorhabditis elegans cGKs regulate growth processes, but also patterns of particular behavioral states (Raizen et al. 2006, 2008, Fujiwara et al. 2002), odor perception, and signal integration (Lee et al. 2010). Finally, genome sequencing approaches have led to the identification of cGK orthologs also from protozoa. Here, variation in the number of cGMP-binding sites was observed. Surprisingly, 
a role for cGKs in regulating locomotion processes emerges as a common functional theme between protozoa and higher eukaryotes (Baker and Deng 2005).

Schistosomiasis is a disease of worldwide significance for humans and animals and is caused by parasitic helminths of the genus Schistosoma (Savioli et al. 2009, Quack et al. 2006). Ambitious efforts have been made in the last decade to develop an effective vaccine against schistosomiasis, but they are ongoing and no candidate is in sight, ready for application (McManus and Loukas 2008). In addition, there is a pressing need to develop new anthelmintics due to the emerging fear of resistance against the commonly used drug praziquantel (Doenhoff et al. 2008, Melman et al. 2009). Towards this end, research concentrates on the understanding of essential physiological or developmental processes of schistosome biology, because attempts to intervene in these processes will open new ways to control the disease. Schistosome parasites reveal unusual biological features. They are the only members of the trematodes that have evolved separate sexes. Furthermore, a continuous pairing contact is essential for the development of the reproductive organs, ovary and vitellarium, of the female (Kunz 2001, LoVerde et al. 2004, Grevelding 2004), which is a prerequisite for egg production. Approximately $30-50 \%$ of eggs reach the environment of a definitive host to complete the life cycle (Moore and Sandground 1956). The remaining eggs are deposited in the host tissue, such as spleen or liver, causing severe pathogenesis, while the worm burden itself has less impact (Ross et al. 2002). As typical for trematodes schistosomes produce composite eggs consisting each of one oocyte, produced in the ovary, and 30-40 vitelline cells with nurse cell character, delivered by the vitellarium. During recent years data have been obtained indicating that developmental processes leading to female reproductive activity are controlled by signal transduction processes. Besides receptor tyrosine kinases (RTKs), a variety of cellular protein tyrosine kinases (CTKs) have been identified and shown to play important roles during gonad differentiation in both genders (Ahier et al. 2008, LoVerde et al. 2009, Beckmann et al. 2010a).

In this study we made use of the great amount of transcriptome and genome data obtained from differ- ent initiatives during the last decade to decipher the genetic equipment of schistosomes (Verjovski-Almeida et al. 2004, Haas et al. 2007, Oliveira et al. 2008, Berriman et al. 2009). By homology screening we identified members of the class of cGKs in S. mansoni, of which one was characterized in this study. We provide first evidence that SmcGK1 is expressed in the adults, being controlled by antisense regulation. Localization studies pointed to a role of SmcGK1 in the gonads of both genders. Furthermore, inhibitor studies in adult schistosomes in vitro indicated further roles of cGKs, probably associated with muscle activity.

\section{MATERIALS AND METHODS}

\section{PARASITE STOCK}

The parasite life cycle was maintained in the laboratory using a Liberian isolate of Schistosoma mansoni (Grevelding 1995), Biomphalaria glabrata as intermediate snail host, and Syrian hamsters (Mesocricetus auratus) as final host. Hamsters were perfused 42-49 days after infection to obtain adult worms. To produce single sex male or female worms, snails were infected with one miracidium only to generate unisexual cercariae, which were used for final host infection.

All experiments with hamsters have been done in accordance with the European Convention for the Protection of Vertebrate Animals used for Experimental and other Scientific Purposes (ETS No 123; revised Appendix A) and have been approved by the Regional Council (Regierungspraesidium) Giessen (V54-19 c 20/ 15 c GI 18/10).

\section{ISOLATION OF NUCLEIC ACIDS}

Isolation of genomic DNA and total RNA was performed as described elsewhere (Grevelding 1995, Beckmann et al. 2010b). In short, DNA was isolated by a proteinase K-based procedure, followed by phenol/chloroform extraction and ethanol precipitation before resuspension in $\mathrm{dH}_{2} \mathrm{O}$. Total RNA was extracted using TriFast (PeqLab) following the manufacturer's instructions. Residual DNA remaining in the RNA preparations was removed by DNase digestion using RNase-free DNaseI (Fermentas). 


\section{CLONING AND SEQUENCING}

Following total RNA extraction, cDNA synthesis was performed with the Quantitect Reverse Transcription Kit (Qiagen), following the manufacturer's protocol. Due to the length of the transcript three different primer combinations were used for PCR to amplify different parts of the transcript (1: fwd 5'-GGTTACATTAAATTATGCGAT-3' + rev 5'-GAGAGAAAGAGGGGGAAATGG-3'; 2: fwd 5'-ACCTCAACAGGCCATAGACG-3' + rev 5'-TTTTGACCAATTCC-AATGTATTTAGC-3'; 3: fwd 5'-TTACTGAAGACGATAGCGTTTGG-3' + rev 5'-TTTTAT-ATTGGTTGCATTCTTGGT-3'). Primer sequences were based on the sequence information available at SchistoDB for the gene prediction Smp_123290 (http://www.genedb.org/Homepage/ Smansoni; Berriman et al. 2009, Zerlotini et al. 2009). For amplification a standard Taq Polymerase (NEB) was used. All PCRs were performed in a final volume of $25 \mu \mathrm{l}$ using primer end concentrations of $800 \mathrm{nM}$ each. PCR products were separated on $1.0 \%$ agarose gels stained with ethidium bromide. The amplicons were cut out from the gel and the DNA extracted using the PeqGold Gel Extraction Kit (Peqlab), following the manufacturer's protocol. Extracted fragments were cloned into pDrive (Qiagen). Sequencing was done commercially (LGC Genomics, Berlin).

\section{RT-PCRs ANALYSING PAIRING-DEPENDENT \\ TRANSCRIPTION AND ANTISENSE DETECTION}

Male and female worms from mixed as well as singlesex infections were used for RNA isolation. To analyze pairing-dependent transcription the following primer combinations were used in a PCR, following a strandspecific RT reaction: the latter was performed using (PKG-RNAr) 5'-CAATGGTCCATTCAATTTAACT-3', which was then combined with (PKG-RNAf) 5'-GTTACATTAAATTATGCGATTT-3' (product size: 452 bp) for PCR. RT was done using $200 \mathrm{ng}$ total RNA and Thermoscript Reverse Transcriptase (Invitrogen) according to the manufacturer's protocol, $1 \mu 1$ of cDNA was entered into PCR reaction.

For detection of anti-sense transcripts the primer (in situ III-5') 5'-TCACAATCAATTAACAGTAG-3' was used for RT. For subsequent PCR in situ III-5' was combined with (in situ III-3') 5'-CTGAACTGCATCTAAATTCTTGATTAAATC-3' (product size: 609 bp) using $5 \mu \mathrm{l}$ of the synthesized cDNA. Further steps were done as above.

\section{In situ HYBRIDIZATION}

In situ hybridization was done following the instructions of an established protocol (Quack et al. 2009) with the following modifications: hybridization temperature was $42^{\circ} \mathrm{C}$, and slides were washed up to $1 \times \mathrm{SSC}$. Three different probes were designed and used in sense and antisense for detection. Probe one is located at position 2572-3087 of the nucleotide sequence (FR749994), probe two at position 1851-2435 and probe three at position 656-1254. Antisense and sense probes for the eggshell protein precursor p14 (Kunz et al. 1987, Köster et al. 1988) were used as positive and negative controls, respectively. The probes fit to the published sequence from nucleotide position 776-1073 (accession number X05841).

\section{INHIBITOR STUDIES AND MORPHOLOGICAL ANALYSES}

For first experiments to interfere with cGK activity in schistosomes, the cGMP analog (PR)-8-pCPT-cGMPS (Rp-8-(4-chlorophenylthio)-guanosine-39,59-cyclic monophosphorothioate) (Biolog, Germany) was used for in vitro studies with adult schistosomes following a previously described procedure (Beckmann et al. 2010b). According to studies on purified cGKs, indicating a $\mathrm{K}_{\mathrm{i}}$ of $0,5 \mu \mathrm{M}$ or $\mathrm{IC}_{50}$ of $18,3 \mu \mathrm{M}$ for cGKI and $\mathrm{IC}_{50}$ of $0,16 \mu \mathrm{M}$ for cGKII (Butt et al. 1994, Gamm et al. 1995) the inhibitor was used in a 100 fold higher concentration of $1 \mathrm{mM}$. Before treatment, couples were left in culture for two days to allow recovery from perfusion stress. For inhibitor treatment experiments we started with 12 couples of $S$. mansoni, with 4 couples taken out for fixation and carmine-red staining every second day. Couples were maintained in a volume of $200 \mu \mathrm{l}$ medium/per couple (M199 [Gibco] including glucose, sodium bicarbonate, 4 (2 hydroxyethyl)-1-piperazineethane sulfonic acid including an antibiotic/antimycotic mixture [1.25\%, Sigma] and FCS [10\%, Gibco] at $37^{\circ} \mathrm{C}$ and $5 \% \mathrm{CO}_{2}$ ), supplemented with $1 \mathrm{mM}$ (PR)8-pCPT-cGMPS. Medium and inhibitor were refreshed every 24 hours during the treatment periods of 2-6 days. 
Fig. $1-\mathbf{A}$, alignment section of the complete coding sequence of SmcGK1 and the partial genomic sequence of Smp_123290 showing its 3' part of the intron 8 and its complete exon 9 (boxed). The additional nucleotide sequence found in SmcGK1 (1896-2060) is marked in light and dark grey. The part of Smp_123290, which had been predicted as intronic, but which was found in our study to be transcribed is marked in dark grey. Nucleotides (82) found to be new in SmcGK1, but which did not occur in Smp_123290, are shown in light grey. B, part of the alignment of the amino acid (aa) sequence of SmcGKI and Smp_123290. The additional 55 aa detected in SmcGKI are marked light grey. C, phylogenetic analysis of SmcGK1 and cGK homologs of human cGKI-beta (CAA68810.1), human cGKI-alpha (BAA08297.1), mouse cGKI-alpha (NP_001013855), mouse cGKI-beta (NP_035290), Drosophila cGKII (NP_477487.1), Caenorhabditis elegans (NP_500141.1), human cGKII (EAX05867), mouse cGKII (NP_032952), Drosophila cGKI (AAB03405.1), Plasmodium falciparum cGK (AAN36959.1). D, part of the multialignment of the aa sequence used in C. Boxed area represents the highly conserved catalytic tyrosine kinase domain.

Morphological analyses were done according to a confocal laser scanning microscopical (CLSM) method described in earlier studies (Machado-Silva et al. 1998, Neves et al. 2005). In short, adult worms were fixed for at least 24 hours in AFA (alcohol 95\%, formalin $3 \%$, and glacial acetic acid $2 \%$ ), stained for 30 minutes with $2.5 \%$ hydrochloric carmine (Certistain ${ }^{\circledR}$, Merck), and destained in acidic 70\% ethanol. After dehydration for 5 minutes in $70 \%, 90 \%$, and $100 \%$ ethanol, respectively, worms were preserved as whole-mounts in Canada balsam (Merck) on glass slides. CLSM images were made on a Leica TSC SP2 microscope using a $488 \mathrm{~nm} \mathrm{He} / \mathrm{Ne}$ laser and a $460 \mathrm{~nm}$ long-pass filter using reflection mode.

\section{In silico ANALYSES}

The following public domain tools were used: SchistoDB (http://www.schistodb.net/schistodb20/; Zerlotini et al. 2009), BLAST (http://www.ncbi.nlm.nih.gov/ BLAST), ClustalW (http://www.ebi.ac.uk/Tools/msa/ clustalw2/), Clustal X, Treeview (Page 1996), and Image J (http://rsb.info.nih.gov/ij/index.html; Rasband, W.S., ImageJ, U.S. National Institutes of Health, Bethesda, Maryland, USA, http://rsb.info.nih.gov/ij/) for densitometric analyses.

\section{RESULTS}

Cloning ANd Characterization OF THE CDNA SEQUENCE OF SMCGK1

In silico search in the Schistosoma genome detected six predictions for cGKs in the Schistosoma genome: Smp_123290, Smp_080860, Smp_151100, Smp_168670,Smp_174820, Smp_078230. Of these we could amplify by RT-PCR Smp_151100, as well as Smp_080-
860 and Smp_078230 which could represent kinase and cGMP binding sites of the same gene. In this study we focused on the characterization of Smp_123290, whose sequence was used as template for primer design and sequence verification resulting in the cloning and characterization of SmcGK1.

After cloning and sequencing of three SmcGK1 subfragments, a full-length coding sequence (CDS) of 3105 nucleotides was reconstructed (accession number FR749994). This sequence was compared to Smp_123290. The in silico prediction of the gene comprised 16 exons and 15 introns with a total of $96.390 \mathrm{bp}$. The cloned SmcGK1 sequence matched to a great extent to Smp_123290, but revealed additional 165 nucleotides at position 1896-2060, of which the last 83 align to the $3^{\prime}$ area of the predicted eighths intron of Smp_123290 (Fig. 1A). The remaining 82 nucleotides did not show similarity to any known sequence according to blast analysis. Figure $1 \mathrm{~B}$ shows the amino acid (aa) sequence alignment of SmcGK1 and Smp_123290 in the area of the resulting 55 additional aa (position 632-686), which are part of the cGMP binding domain of SmcGK1.

Blast analyses with the complete aa sequence of SmcGK1 indicated a greater similarity to type II cGKs of other organisms (Fig. 1C/D). However, the aa sequence of SmcGK1 lacks a myristoylation motive typically found in mammalian membrane-bound cGKII. Phylogenetic analyses indicated that the homology to mammalian cGKII is mainly due to a high similarity of the kinase domains (Fig. 1C). However, a separate analysis of cGMP-binding domains only placed SmcGK1 closer to Drosophila cGKI and C. elegans cGK (result not shown). Thus SmcGK1 seems to occupy an intermediate position with respect to cGK classifications. 

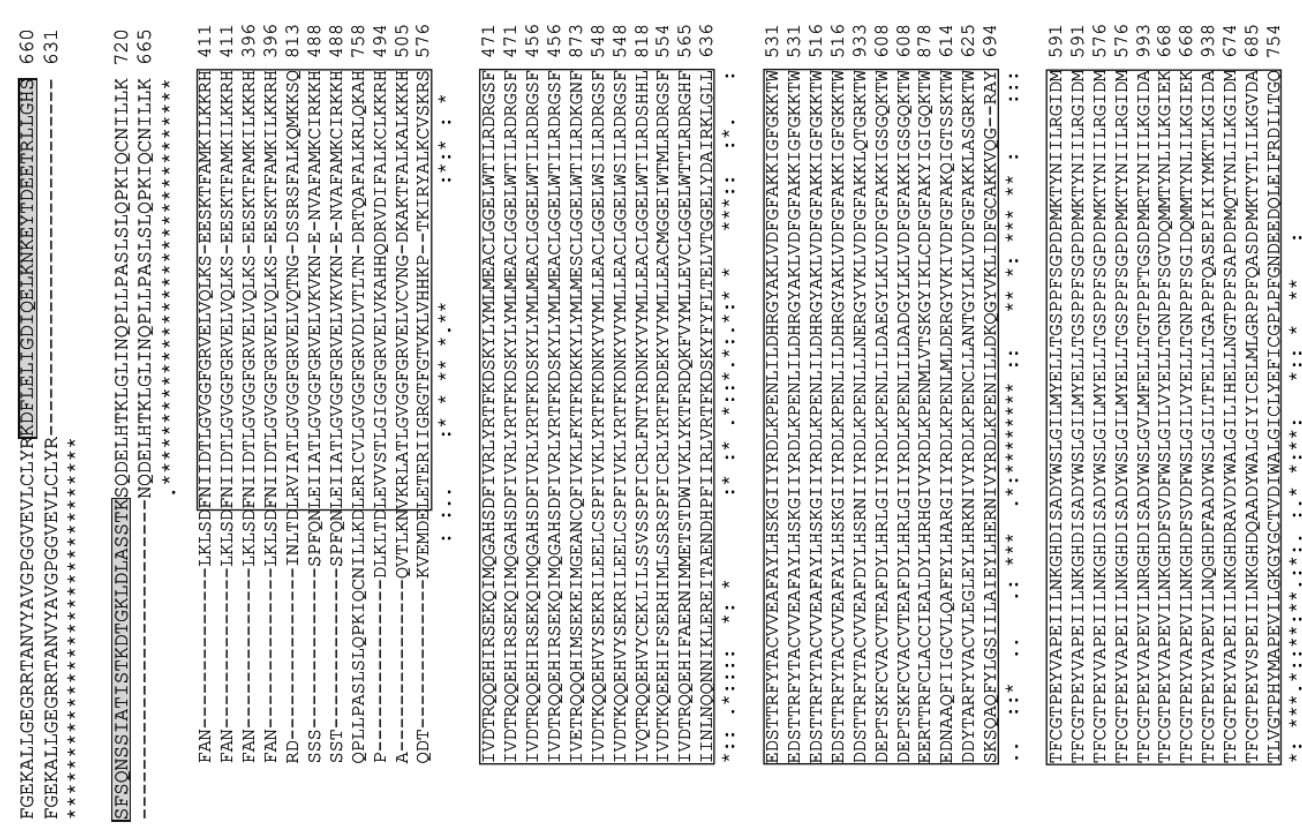

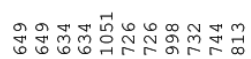

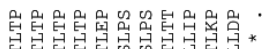

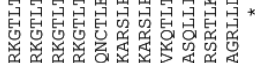

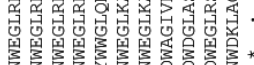

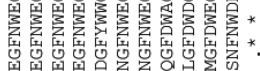

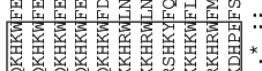

产。

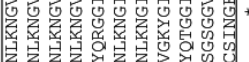

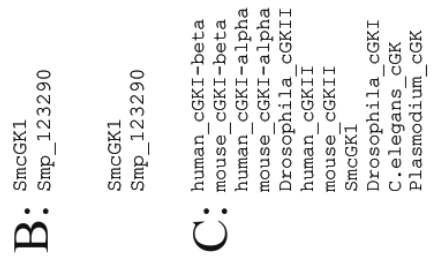

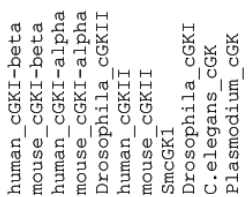

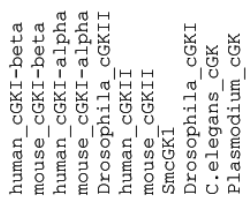

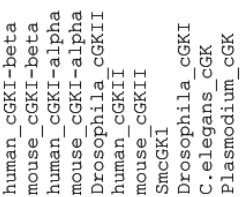
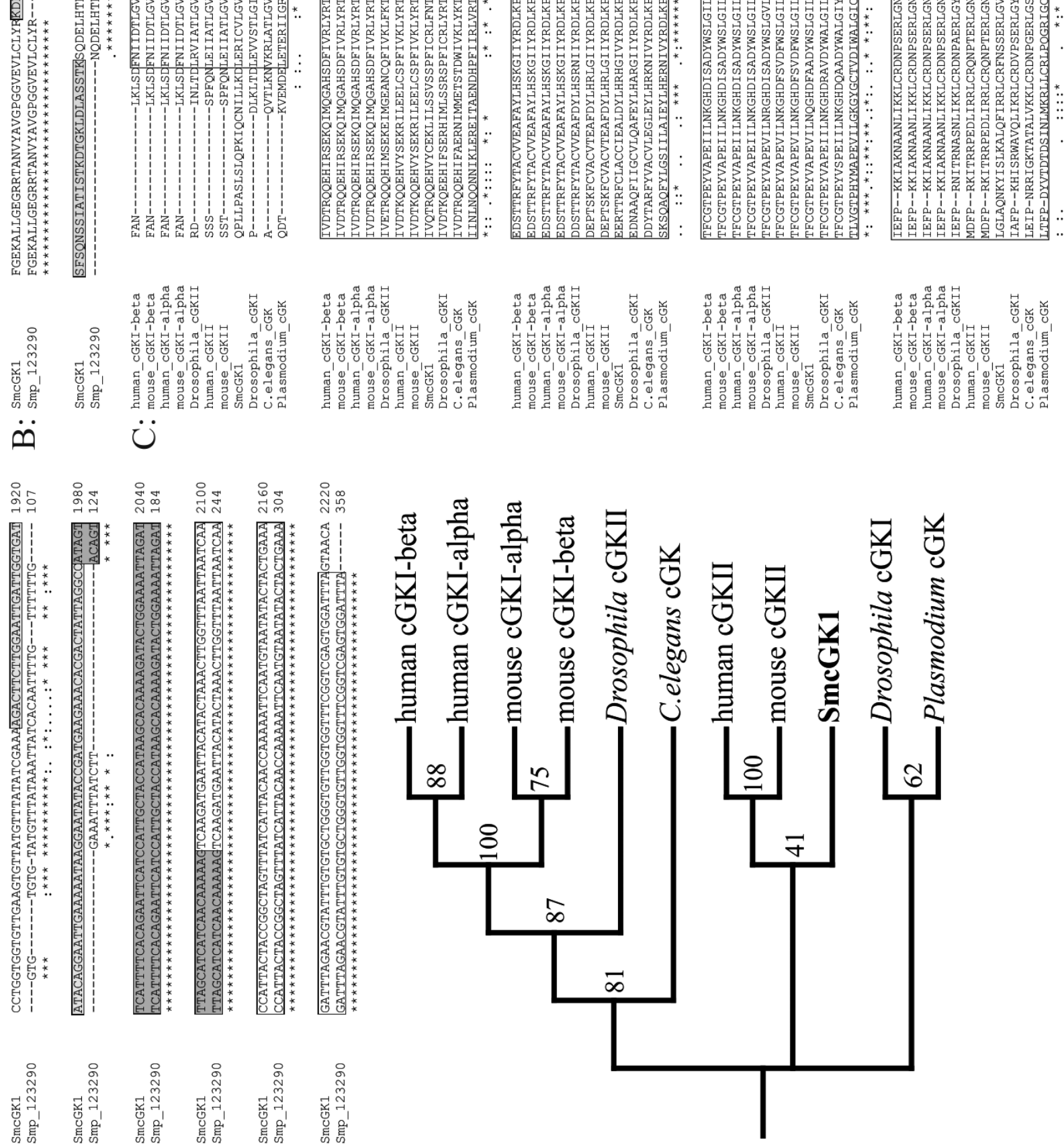

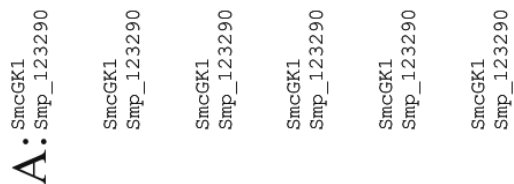

An Acad Bras Cienc (2011) 83 (2) 
SMCGK1 TRANSCRiptional ANALYSES In AdUltS AND IDENTIFICATION OF NATURAL SMCGK1

ANTISENSE TRANSCRIPTS IN ADULT SCHISTOSOMES

To confirm the presence of SmcGK1 in all adult life stages of Schistosoma mansoni RT-PCR reactions were performed with RNAs from pairing-experienced females (ef), pairing-unexperienced females (uf) obtained from hamster infections with unisexual cercariae, pairing-experienced (em) and pairing-unexperienced males (um) obtained in the same way. SmcGK1-specific products were confirmed in all adult stages (Fig. 2A). Control reactions for DNA contamination lacking the enzyme during reverse transcription reactions $\left(\mathrm{RT}^{-}\right)$did not detect DNA in ef, em or um, but in uf, however, the resulting PCR products were unspecific.

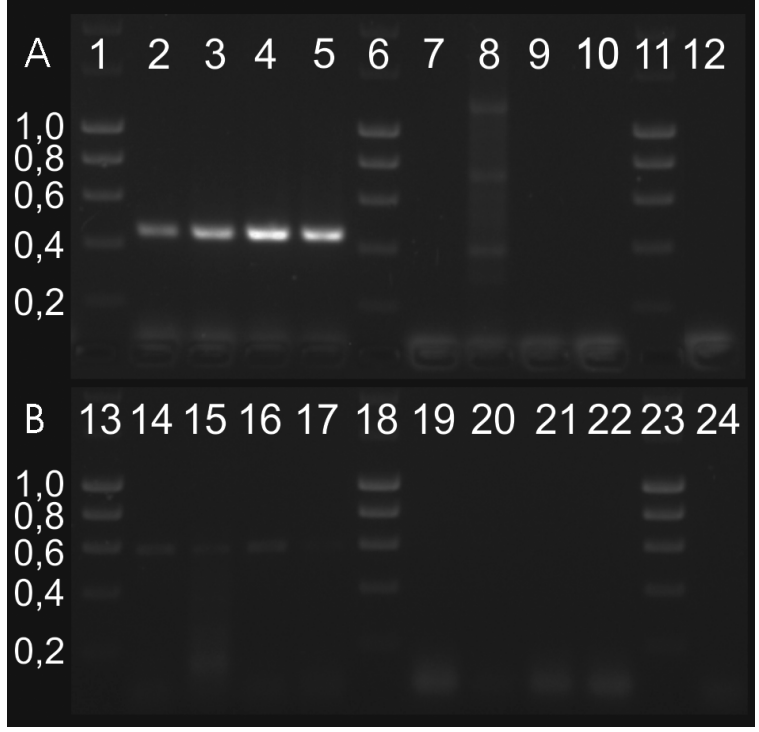

Fig. 2 - A, RT-PCR analyses detecting SmcGK1 transcripts of the expected size (452 bp) in pairing-experienced females (ef; lane 2); pairing-unexperienced females (uf; 3); pairing-experienced males (em; 4); pairing-unexperienced males (um; 5). Controls: ef RT-negative (RT ${ }^{-}$; 7); uf $\mathrm{RT}^{-}$(8); RT without template (9); em $\mathrm{RT}^{-}$(10); um $\mathrm{RT}^{-}(12)$. The unspecific products in lane 8 originated from residual amounts of DNA. Marker: Hyperladder I (Bioline, Germany; sizes given in $\mathrm{kb}$ ), lanes $1,6,11,13,18,23$. B, strand-specific RT-PCR analyses confirming the existence of antisense products ( $609 \mathrm{bp}$ ) in ef (14), uf (15), em (16), and um (17). Controls (lanes 19-22, 24) as in A.

Localization studies by in situ hybridization with paired male and female worms detected SmcGK1 transcripts in the gonads of male and female worms as well as in the vitellarium of the female (Fig. 3). This transcriptional pattern was detected with three different SmcGK1-specific probes in three independent approaches. However, during these experiments we did not only detect sense RNAs, but also received signals for antisense RNAs in the same locations, when SmcGK1 sense probes were used for control purposes. This indicated a putative antisense regulation of this gene, a phenomenon well known for eukaryotes including schistosomes (Verjovski-Almeida et al. 2007). Therefore, as positive and negative controls we included in situ hybridizations with antisense and sense probes of p14 (Kunz et al. 1987), which represents a high abundantly transcribed gene coding for an eggshell precursor protein shown before to be expressed in the vitellarium (Köster et al. 1988).

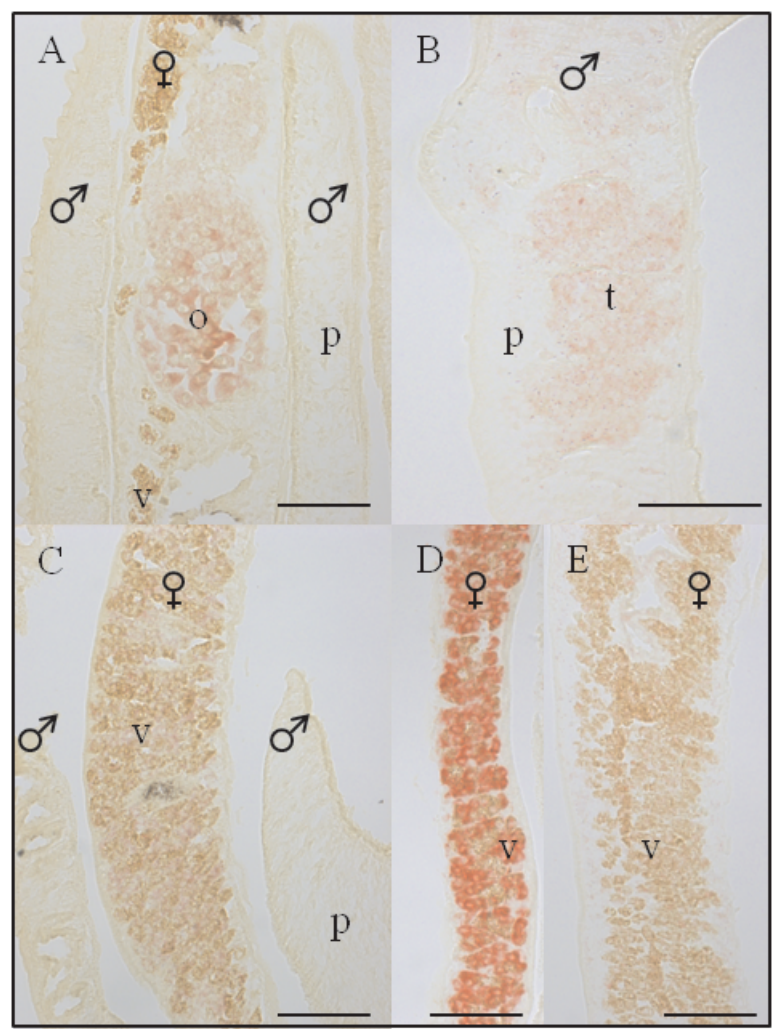

Fig. 3 - In situ hybridization with PKG-specific antisense probes. Pictures are representative for the three different probes as described in materials and methods as well as for the detection of sense transcripts. Detection of SmcGK1 transcript in A, ovary (o), B, testes (t), C, weakly within the vitellarium (v); D, p14 positive control, E, p14 negative control. (scale bar: $50 \mu \mathrm{m}$; p: parenchyma). 
To confirm the specificity of the SmcGK1 antisense signals, strand-specific RT-PCRs were performed using RNAs of ef, uf, em and um as template (Fig. 2B). A specific product could be detected in all tested stages, and no DNA contamination was found in $\mathrm{RT}^{-}$controls. Cloning and sequencing of this PCR product finally confirmed its SmcGK1 origin. The occurrence of SmcGK1 sense and antisense transcripts was also confirmed by transcriptome analyses using microarrays and SuperSAGE (Leutner et al., in preparation).

\section{INHIBITOR StUdies to INFLUENCE SMCGK1 ACTIVITY}

To functionally test SmcGK activity and its putative role for schistosome physiology, worm couples were treated with the inhibitory cGMP analog (PR)-8-pCPTcGMPS. Previous studies on the activity of purified human platelet or mouse intestine cGKI as well as recombinantly expressed and purified cGKII determined a higher specificity of the inhibitor for cGKII than cGKI (Butt et al. 1994, Gamm et al. 1995). As the inhibitory effect in these studies was reported to occur in $\mu$ molar doses of the inhibitor, we performed an initial experiment to determine the inhibitory dose for schistosomes (data not shown). As the concentration of $1 \mathrm{mM}$ proved to induce a behavioral phenotype in comparison to control this concentration was used for subsequent experiments. Over a treatment period of six days we observed that more couples separated following inhibitor treatment compared to an untreated control group. When couples separated in the control population, they repaired after a short time, whereas treated worms never repaired after separation. In addition, clear differences were seen in the movement pattern between treated and control group. During the first two days the movement of control worms was smooth and swift, whereas the movement of treated worms was choppy. Separation of couples occurred, and separated males started to curl in a screw-like fashion. From 3-6 days on, more couples were separated and movement slowed down progressively, which resulted in a slow motion (slomo) phenotype (supplementary data videos A, B; http://www.unigiessen.de/cms/fbz/fb10/institute_klinikum/ institute/parasitologie/forschung/schisto/publikationen/mehr).

To investigate possible changes at the morpho- logical level, worms were stained with carmine red after 2, 4 and 6 days and studied by CLSM. While we were not able to detect a morphological difference between treated and control males by CLSM, we found a kind of oocyte congestion within the oviduct of the females (Fig. 4A 1-3). In untreated control worms (Fig. 4A 4), migrating oocytes are rarely detected within the oviduct on their way towards the ootype (Beckmann et al. 2010a, b; this study). In inhibitor-treated females a high number of eggs were detected at the same time within the oviduct. Furthermore, an apoptosis-like degradation of oocytes occurred. Depending on the worm batch used, this effect was already seen at day 2 following treatment or later. This effect also increased with the time of treatment. Correspondingly to this phenotype, egg production was affected. Already at day 1 following treatment the number of eggs of treated couples was lower compared to that of untreated control couples (Fig. 4B). Egg production of adults is generally decreasing under in vitro culture conditions, which leads to a leveling of egg numbers in treated and untreated worms after about one week ( 2 days ahead of treatment, 5 days treatment period).

\section{DISCUSSION}

Searching for cGK homologs in the schistosome genome data set led to the identification of six predictions for schistosome cGMP-dependent protein kinases. Cloning and sequencing of cDNA parts of Smp_123290 from our Liberian strain of S. mansoni (Grevelding 1995), and reconstruction of the full-length cDNA sequence showed a difference of additional 165 ORFassociated nucleotides to the predicted sequence. This finding could be due to an inaccurate prediction of the coding sequence at this site, or a difference between the Liberian strain of $S$. mansoni used in our study and the Porto Rico strain used in the genome project. Data base analyses of the full-length cDNA sequence, as well as phylogenetic analyses hint at an intermediate position of SmcGK1 concerning its classification within the cGKs. The sequence showed significant homology to the kinase domain of mammalian cGKII, but was closer to invertebrate sequences concerning its cGMP binding sites. RT-PCR analyses demonstrated a pairingindependent transcriptional profile in adults. Localiza- 


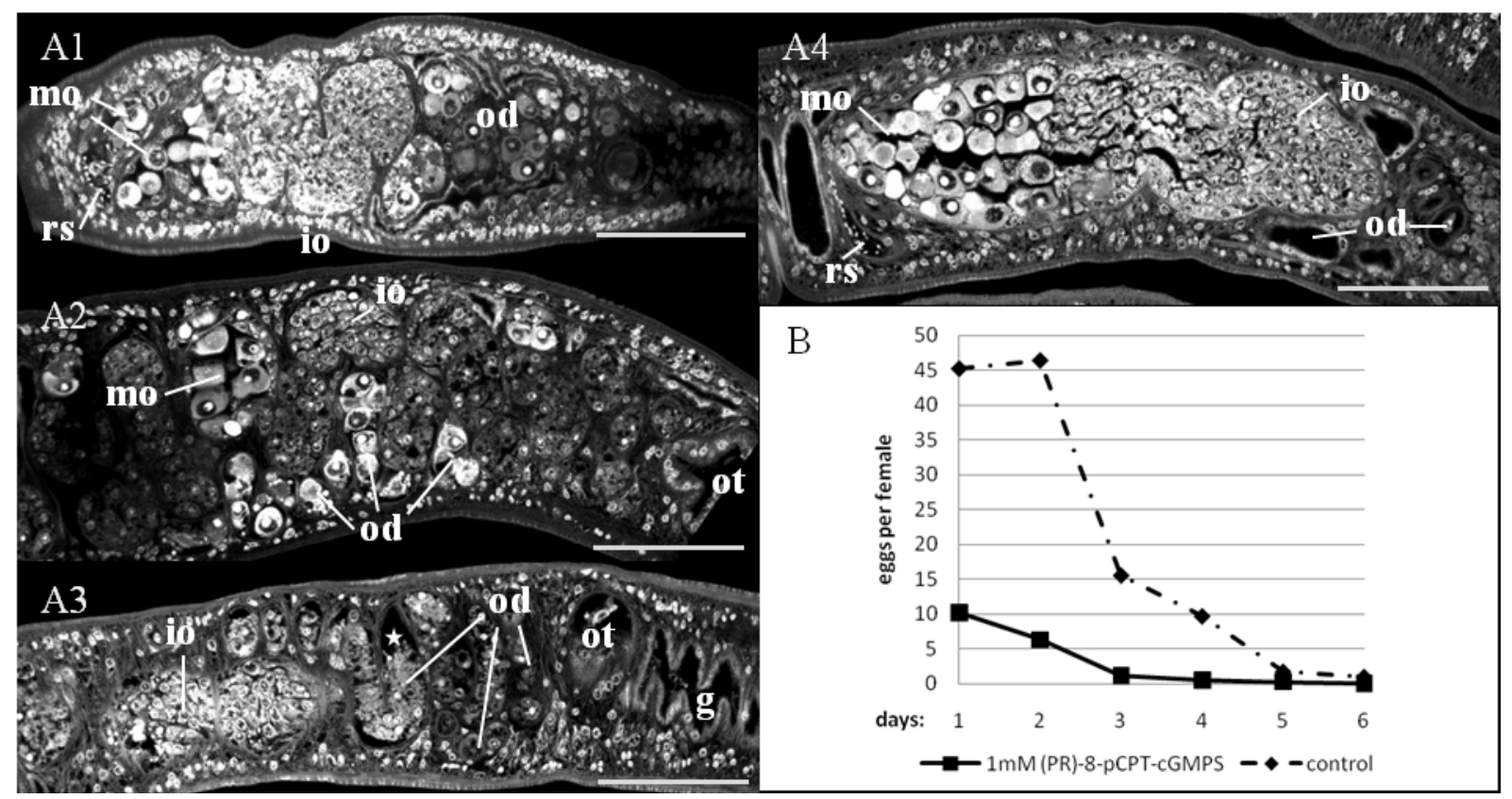

Fig. 4 - Effects of inhibitor treatment on female morphology (analyzed by confocal laser scanning microscopy) and egg production (analyzed in vitro). A, influence of inhibitor treatment on the ovary and oviduct of a female worm treated with inhibitor for A1: two days, A2: four days, A3: six days; A4: untreated control after two days, which is representative for days 4-6 (scale bar: 75 $\mu \mathrm{m}$; g: gut; io: immature oocytes; mo: mature oocytes; od: oviduct; ot: ootype; rs: receptaculum seminis). B, comparison of egg production of inhibitor-treated (1 mM) versus control females, showing eggs per day and female. Supplementary data: videos showing treated (A) and control (B) worms in vitro at day 4 of the experiment. http://www.unigiessen.de/cms/fbz/fb10/institute_klinikum/institute/parasitologie/forschung/schisto/publikationen/mehr

tion studies exhibited transcription in the reproductive organs of both genders. Unexpectedly, SmcGK1 transcripts were repeatedly detected in control reactions during in situ hybridization, for which labeled sense transcripts were used. This pointed to the presence of SmcGK1 antisense transcripts naturally occurring in these tissues, a hypothesis which was confirmed by RT-PCR detection and sequencing of SmcGK1 antisense transcripts from adult worms. Research of the last couple of years exhibited that post-transcriptional gene regulation by antisense RNA is a widespread phenomenon in eukaryotes (Ryusuke and Slack 2007, Siomi and Siomi 2010). This includes schistosomes, since in a former microarray analysis first genome-wide evidence was obtained for the antisense regulation of about $7 \%$ of schistosome genes (Verjovski-Almeida et al. 2007).

To obtain first functional evidence for the importance of SmcGK1 for schistosome biology we performed an inhibitor approach with adult schistosomes in vitro using a cGMP analog, which was proven before to be able to block the activity of cGKI from human platelets or cGKI/cGKII from mouse (Butt et al. 1994, Gamm et al. 1995). During treatment periods for 2-6 days in vitro we monitored worms at a daily basis and, in addition, performed CLSM for morphological analysis as described before (Machado-Silva et al. 1998, Neves et al. 2005, Beckmann et al. 2010a, b). Monitoring revealed a slomo effect on adults, which we first observed after 3 days of treatment, increasing in intensity until day 6. During the same time intervals, controls behaved in a normal way. Since cGKs are known to be key players in signaling cascades of muscle cells (Schlossman et al. 2003, Hofmann et al. 2009), it is tempting to speculate that SmcGKs may also be involved in such activities. Since SmcGK1 transcriptional activity was mainly detected in the ovary, vitellarium, and testes upon in situ hybridization, we may have missed SmcGK1 transcript detection in the muscle area. Alternatively, this phenotype could have originated from blocking the activity of one of the iso- 
forms of SmcGKs, which may have been affected by the inhibitor as well. Due to lower degrees of homology we were not able to classify the other SmGKs unequivocally. In addition to the slomo phenotype, we observed peculiar changes at the morphological level. By CLSM major changes in ovary, ootype, or testes morphology were not detected, although the structure of the ovary seemed to vary to some extent with increasing inhibitor concentrations. Within the oviduct, however, which connects the ovary with the ootype allowing oocytes to be fertilized and transported, an atypical oocyte congestion was observed in treated females. This finding indicates that the transport of mature oocytes is hampered. It is tempting to speculate that this observation may coincide with the putatively decreasing motor activity of slomo males. Assumed that the constant pairing combined with the regular peristaltic, wavelike movements of the muscular male body could have a massaging effect on the female and thus contribute to the transport of oocytes and eggs, both oocyte congestion and reduction of egg production could be explained. The latter is probably also influenced by apoptotic processes in oocytes starting early after treatment.

Due to their involvement in similar physiological processes cGKs have also come into focus of protozoan research and are considered as drug targets (Taylor et al. 2010, Diaz et al 2005, Donald et al. 2002). In Eimeria growth was negatively affected by trisubstituted pyrrole, a potent cGK inhibitor (Gurnett et al. 2002). cGKs participate in gliding motility of Plasmodium (Moon et al. 2009), Eimeria and Toxoplasma and is involved in the host invasion of the latter two parasites (Wiersma et al. 2004). Also, in Plasmodium they influence blood-stage schizogony (Taylor et al. 2010), merosome egress from liver cells (Falae et al. 2010), and finally influence gametogenesis (McRobert et al. 2008). In eukaryotes cGKs play diverse physiological functions (Lohmann and Walter 2005), among which a cGMP/PKG pathway was hypothesized to be involved in oocyte maturation (Petr et al. 2006, Zhang et al. 2005).

To elucidate the biological roles of SmcGKs in more detail, further studies have to be performed including experiments to confirm the remaining gene predictions, the use of a variety of different inhibitors, and - in the light of antisense regulation of this gene a filed strategy for knock-down approaches. The findings of our study indicate that a cGK inhibitor exists being able to block SmcGK activity in such a way that important physiological processes in schistosomes are negatively affected: motor activity in males and egg production in females. This provides a novel perspective towards the identification of target structures for the design of alternative ways to fight schistosomes, which is urgently needed in the light of the fact that praziquantel is the only widely used drug to treat schistosomiasis evoking the fear of emerging resistance (Doenhoff et al. 2008, Stothard et al. 2009).

\section{ACKNOWLEDGMENTS}

The authors thank Christine Henrich and Gabriele Lang for their excellent technical assistance, Thomas Quack for general support as well as Anne Holz and Adrian Dorresteijn for help with confocal microscopy. This work was supported by the Studienstiftung des Deutschen Volkes (SL) and a grant of the Deutsche Forschungsgemeinschaft (GR-1549/7-1).

\section{RESUMO}

Esquistossomos são parasitas trematodos de importância médica em todo o mundo para o homem e os animais. O crescimento e o desenvolvimento destes parasitas requerem um ambiente específico do hospedeiro, mas também um processo de comunicação permanente entre parasitas dos dois sexos. Evidência molecular tem se acumulado e indica que as interações são mediadas por processos de transdução de sinal. Moléculas sinalizadoras conservadas foram identificadas, e as primeiras abordagens têm sido feitas para sua caracterização. Contudo, não foi ainda descrito nenhum representante da família conservada das proteína-quinases dependentes de cGMP (cGKs) neste parasita. Analisando o genoma do Schistosoma mansoni nós identificamos homólogos de cGK, dos quais um foi investigado em mais detalhe no presente estudo. Aqui apresentamos a clonagem do gene SmcGK1, cuja sequência mostra homologia com cGKs de eucariotos superiores. SmcGK1 foi detectada como sendo transcrita de forma gêneroindependente em esquistossomos adultos. A ocorrência de transcritos de SmcGK1 senso e antisenso sugere que a expressão deste gene é controlada em nível pos-transcricional. 
Experimentos de hibridização in situ demonstraram uma expressão preferencial nas gônadas em ambos os gêneros, indicando um papel para SmcGK1, pelo menos durante o desenvolvimento de esquistossomos. Usando um inibidor específico de cGK para tratamento de esquistossomos adultos in vitro finalmente resultou em um fenótipo multifacetado, incluindo movimentos lentos, congestão dos oócitos, e redução da produção de ovos.

Palavras-chave: Schistosoma mansoni, transdução de sinal, proteína-quinases dependentes de cGMP (cGKs), serina/treonina $(\mathrm{S} / \mathrm{T})$ quinases, desenvolvimento gonadal.

\section{REFERENCES}

Ahier A, Khayath N, Vicogne J And Dissous C. 2008. Insulin receptors and glucose uptake in the human parasite Schistosoma mansoni. Parasite 15: 573-579.

BAKER DA AND DENG W. 2005. Cyclic GMP-dependent protein kinases in protozoa. Front Biosci 10: 1229-1238.

Beckmann S, Quack T, Burmeister C, Buro C, Long T, Dissous C And Grevelding CG. 2010a. Schistosoma mansoni: signal transduction processes during the development of the reproductive organs. Parasitology 137: 497-452.

Beckmann S, Buro C, Dissous C, Hirzmann J And Grevelding CG. 2010b. The Syk kinase SmTK4 of Schistosoma mansoni is involved in the regulation of spermatogenesis and oogenesis. PLoS Pathog 6(2): e1000769.

BerRiman M ET AL. 2009. The genome of the blood fluke Schistosoma mansoni. Nature 460: 352-358.

Butt E, Eigenthaler M AND Genieser HG. 1994. (Rp)-8-pCPT-cGMPS, a novel cGMP-dependent protein kinase inhibitor. Eur J Pharmacol 269: 265-268.

Diaz CA, Allocco J, Powles MA, Yeung L, Donald RGK, ANDERSON JW AND Liberator PA. 2005. Characterization of Plasmodium falciparum cGMP-dependent protein kinase (PfPKG): Antiparasitic activity of a PKG inhibitor. Mol Biochem Parasitol 146: 78-88.

Doenhoff MJ, Cioli D And Utzinger J. 2008. Praziquantel: mechanisms of action, resistance and new derivatives for schistosomiasis. Curr Opin Infect Dis 21: 659-667.

Donald RGK, Allocco J, Singh SB, Nare B, Salowe S, Wiltsie J And Liberator P. 2002. Toxoplasma gondii Cyclic GMP-Dependent Kinase: Chemotherapeu- tic Targeting of an Essential Parasite Protein Kinase. Eukaryot Cell 1: 317-328.

Falae A, Combe A, Amaladoss A, Carvalho T, MEnARD R AND Bhanot P. 2010. Role of Plasmodium berghei cGMP-dependent protein kinase in late liver stage development. J Biol Chem 285: 3282-3288.

Fujiwara M, SEngupta P And McIntire SL. 2002. Regulation of body size and behavioral state of C. elegans by sensory perception and the EGL-4 cGMP-dependent protein kinase. Neuron 36: 991-993.

GAMM DM, Francis SH, ANGELOTTI TP, CORBIN JD AND UHLER MD. 1995. The Type II Isoform of cGMPdependent Protein Kinase Is Dimeric and Possesses Regulatory and Catalytic Properties Distinct from the Type I Isoforms. J Biol Chem 270: 27380-27388.

Grevelding CG. 1995. The female-specific W1 sequence of the Puerto Rican strain of Schistosoma mansoni occurs in both genders of a Liberian strain. Mol Biochem Parasitol 71: 269-272.

Grevelding CG. 2004. Schistosoma. Curr Biol 14: R545.

Gurnett AM ET AL. 2002. Purification and molecular characterization of cGMP-dependent protein kinase from Apicomplexan parasites. A novel chemotherapeutic target. J Biol Chem 277: 15913-15922.

haAs BJ, Berriman M, Hirai H, Cerqueira GG, LOVERdE PT AND EL-SAYEd NM. 2007. Schistosoma mansoni genome: closing in on a final gene set. Exp Parasitol 117: 225-228.

HoFmann F, Bernhard D, LUKOWSKI R AND WeinMEISTER P. 2009. cGMP regulated protein kinases (cGK). Handb Exp Pharmacol 191: 137-162.

Köster B, Dargatz H, Schröder J, Hirzmann J, HAARMANN C, SYMmons P AND Kunz W. 1988. Identification and localisation of the products of a putative eggshell precursor gene in the vitellarium of Schistosoma mansoni. Mol Biochem Parasitol 31: 183-198.

KUNZ W. 2001. Schistosome male-female interaction: induction of germ-cell differentiation. Trends Parasitol 17: 227-231.

Kunz W, Opatz K, Finken M and Symmons P. 1987. Sequences of two genomic fragments containing an identical coding region for a putative egg-shell precursor protein of Schistosoma mansoni. Nucl Acids Res 15: 5894.

LeE Ji, O'Halloran DM, EAstham-Anderson J, JuAng BT, Kaye JA, Scott Hamilton O, Lesch B, Goga A And L'Etoile ND. 2010. Nuclear entry of a cGMP-dependent kinase converts transient into longlasting olfactory adaptation. Proc Natl Acad Sci USA 107: 6016-6021. 
LOHMANN SM AND WALTER U. 2005. Tracking functions of cGMP-dependent protein kinases (cGK). Front Biosci 10: $1313-1328$.

LoVerde PT, ANDrade LF AND Oliveira G. 2009. Signal transduction regulates schistosome reproductive biology. Curr Opin Microbiol 12: 422-428.

LoVerde PT, Niles EG, Osman A ANd Wu WJ. 2004. Schistosoma mansoni male-female interactions. Can J Zool 82: 357-374.

Machado-Silva JR, Pelajo-Machado M, LenZI HL AND GOMES DC. 1998. Morphological study of adult male worms of Schistosoma mansoni Sambon, 1907 by confocal laser scanning microscopy. Mem Inst Oswaldo Cruz 93(Suppl 1): 303-307.

McManus DP AND LoukAS A. 2008. Current Status of Vaccines for Schistosomiasis. Clin Microbiol Rev 21: 225-242.

McRobert L, Taylor CJ, Deng W, Fivelman QL, Cummings RM, Polley SD, Billker O AND BAKER DA. 2008. Gametogenesis in malaria parasites is mediated by the cGMP-dependent protein kinase. PLoS Biol 6(6): e139.

Melman SD ET AL. 2009. Reduced susceptibility to praziquantel among naturally occurring Kenyan isolates of Schistosoma mansoni. PLoS Negl Trop Dis 3(8): e504.

Moon RW, TAYlor CJ, Bex C, Schepers R, Goulding D, JANSE CJ, WATERS AP, BAKER DA AND Billker O. 2009. A cyclic GMP signalling module that regulates gliding motility in a malaria parasite. PLoS Pathog 5(9): e1000599.

MOORE DV AND SANDGROUND JH. 1956. The relative egg production capacity of Schistosoma mansoni and Schistosoma japonicum. Am J Trop Med Hyg 5: 831-1382.

Neves RH, DE LAmare BC, Machado-Silva JR, CARVALHO JJ, BRANQUINHO TB, LENZI HL, HuLSTIJN M AND GOMES DC. 2005. A new description of the reproductive system of Schistosoma mansoni (Trematoda: Schistosomatidae) analyzed by confocal laser scanning microscopy. Parasitol Res 95: 43-49.

Oliveira G, Franco G and Verjovski-Almeida S. 2008. The Brazilian contribution to the study of the Schistosoma mansoni transcriptome. Acta Trop 108: 179-182.

PAGE R DM. 1996. TREEVIEW: An application to display phylogenetic trees on personal computers. Comp Appl Biosci 12: 357-358.

Petr J, Rajmon R, Chmelíková E, Tománek M, LÁNSKÁ V, PRIBÁNOVÁ M AND JÍLEK F. 2006. Nitric- oxide-dependent activation of pig oocytes: the role of the cGMP-signalling pathway. Zygote 14: 9-16.

Pfeifer A, Ruth P, Dostmann W, Sausbier M, Klatt P And Hofmann F. 1999. Structure and function of cGMP-dependent protein kinases. Rev Physiol Biochem Pharmacol 135: 105-149.

QUACK T, BECKMANN S AND GREVELding CG. 2006. Schistosomiasis and the molecular biology of the malefemale interaction of $S$. mansoni. Berl Munch Tierarztl Wochenschr 119: 365-372.

Quack T, Knobloch J, Beckmann S, Vicogne J, Dissous C And Grevelding CG. 2009. The forminhomology protein SmDia interacts with the Src kinase SmTK and the GTPase SmRho1 in the gonads of Schistosoma mansoni. PloS One 4: e6998.

RAIZEN DM, CUllison KM, PACK AI AND SUndaram MV. 2006. A novel gain-of-function mutant of the cyclic GMP-dependent protein kinase egl-4 affects multiple physiological processes in Caenorhabditis elegans. Genetics 173: 177-187.

RAIZEN DM, ZIMMERMAN JE, MAYCOCK MH, TA UD, You YJ, SUNDARAM MV AND PACK AI. 2008. Lethargus is a Caenorhabditis elegans sleep-like state. Nature 451: 569-572.

Ross AG, Bartley PB, Sleigh AC, Olds GR, Li Y, Williams GM AND MCMANUS DP. 2002. Schistosomiasis. N Engl J Med 346: 1212-1220.

RyUsuke NIWA R AND Slack FJ. 2007. The evolution of animal microRNA function. Curr Opin Genet Dev 17: $1-6$.

Savioli L, Gabrielli AF, Montresor A, Chitsulo L AND ENGELS D. 2009. Schistosomiasis control in Africa: 8 years after World Health Assembly Resolution 54.19. Parasitology 136: 1677-1681.

Schlossmann J, Feil R and Hofmann F. 2003. Signaling through NO and cGMP-dependent protein kinases. Ann Med 35: 21-27.

Siomi H AND Siomi MC. 2010. Posttranscriptional regulation of microRNA biogenesis in animals. Mol Cell 38: 323-332.

Stothard JR, Chitsulo L, KRISTEnSEN TK AND UtZINGER J. 2009. Control of schistosomiasis in subSaharan Africa: progress made, new opportunities and remaining challenges. Parasitology 136: 1665-1675.

TAYlor HM, McRobert L, Grainger M, SicArd A, Dluzewski AR, Hopp CS, Holder AA AND BAKER DA. 2010. The malaria parasite cyclic GMP-de- 
pendent protein kinase plays a central role in blood-stage schizogony. Eukaryot Cell 9: 37-45.

Verjovski-Almeida S, Leite LC, Dias-Neto E, MENCK CF AND WILSON RA. 2004. Schistosome transcriptome: insights and perspectives for functional genomics. Trends Parasitol 20: 304-308.

VerJovski-Almeida S, VenANCio TM, Oliveira KC, Almeida GT AND DEMARCo R. 2007. Use of a 44k oligoarray to explore the transcriptome of Schistosoma mansoni adult worms. Exp Parasitol 117: 236-245.

Wiersma Hi, Galuska SE, Tomley FM, Sibley LD, LIBERATOR PS AND DONALD RGK. 2004. A role for coccidian cGMP-dependent protein kinase in motility and invasion. Int J Parasitol 34: 369-380.
Zerlotini A, Heiges M, Wang H, Moraes RlV, Dominitini AJ, Ruiz JC, Kissinger JC AND OliVEIRA G. 2009. SchistoDB: a Schistosoma mansoni genome resource. Nucl Acids Res 37: D579-582.

Zhang M, Tao Y, Xia G, Xie H, Hong H, Wang F AND LEI L. 2005. Atrial natriuretic peptide negatively regulates follicle-stimulating hormone-induced porcine oocyte maturation and cumulus expansion via cGMP-dependent protein kinase pathway. Theriogenology 64: 902-916. 